\title{
English for specific technical and engineering academic purposes: An analysis on ESL practitioners' challenges
}

\author{
Nor Yazi Khamis', Azwin Arif Abdul Rahim², Supyan Hussin ${ }^{3}$ \\ ${ }^{1,2}$ Department of English Language, Centre for Modern Languages, Universiti Malaysia Pahang, Malaysia \\ ${ }^{3}$ Sustainability of Language Sciences Research Center, Faculty of Social Sciences and Humanities, \\ Universiti Kebangsaan Malaysia, Malaysia
}

\begin{tabular}{l} 
Article Info \\
\hline Article history: \\
Received Aug 27, 2019 \\
Revised Oct 29, 2019 \\
Accepted Nov 25, 2019
\end{tabular}

\section{Keywords:}

English for specific academic purposes

Practitioners

Technical and engineering competency

\begin{abstract}
The facilitation of English for Specific Engineering Academic Purposes approach at Malaysian technical and engineering tertiary institutions is an effort to revitalise the pedagogical methods of ESL learning and communication skills at the institutions. A close examination on the ESL practitioners' context has indicated a critical gap between the diversified requirements of skills and sound pedagogical models to determine the practitioners' quality. In understanding the necessity of the approach, this study aims to explore and investigate the challenges faced by the practitioners in facilitating the approach. The study comprised data gathered from semi structured interviews of 14 ESL experts and an online survey on 42 ESL practitioners in technical and engineering fields. Interview questions for the experts were developed to find out about the challenges and competencies to overcome the hurdles. A self-assessed instrument with a five-Likert scale of importance on the competencies was used to gauge the practitioners' view onn the approach. Frequencies and percentages, and Braun and Clarke's (2006) six-stage method of thematic analysis were used to analyse the data. Findings from the both inquiries revealed several challenges which led to the necessity of wider knowledge and understanding of the approach and the prevalent of specific competencies for the practitioners in overcoming the challenges. The practitioners' competency was substantially indispensable because it could affect their learners' interest in learning the skills as well as in understanding the content subject.
\end{abstract}

Copyright $\odot 2019$ Institute of Advanced Engineering and Science. All rights reserved.

\section{Corresponding Author:}

Nor Yazi Khamis,

Department of English Language, Centre for Modern Languages

Universiti Malaysia Pahang,

26600 Pekan, Pahang, Malaysia.

Email: nyazi@ump.edu.my

\section{INTRODUCTION}

The facilitation of English for Specific Academic Purposes particularly for engineering and technical context which is termed as ESEP (English for Specific Engineering academic Purposes) in this study, certainly entails developing and assisting learners' language study to perform effectively in an academic context. The both focus more on language in context, rather than ESL grammar and structures for fluency in daily, informal settings. The focus influences the way the language and communication are taught and evidently ESAP needs to be more practically diversified, encompassing linguistic, cognitive and sociocultural or psychological aspects [1]. Correspondingly, this connotes the needs for pedagogical methods that are parallel with the engineering education developments [2]. In other words, despite the wide spread distribution of the approach which has broadened ESL practitioners' scopes, ESEP facilitation is foregrounded by the specificity $[3,4]$ of technical and engineering academic contexts. 
Inasmuch, the practitioners are confronted with various challenges from stakeholders who demanded engineers to have a good command of the language. The practitioners need to keep in pace with the rapid worldwide development in engineering education for the past two decades [5]. Puteh and Mohd Ismail also urge for significant changes to the existing pedagogical approach in the field due to its significant roles [6], in preparing engineering learners with future workplace and environment [7]. More specifically, the practitioners should be able to interpret the needs, design syllabi, select and exploit appropriate materials to tailor to specific disciplinary contents and tasks [8-10]. However, Shatrova contends the complications of the roles as it involves decision making about curricula [11]. The practitioners are challenged with teaching unfamiliar disciplines and the need to engage with subject specialists. These have caused the practitioners to face 'subject knowledge dilemma' [12], and feel tension in their desire to overcome the inferiority complex, in proving to be 'intellectually capable' of coping with subject content [13].

Nevertheless, despite the growing pressures on the practitioners in facilitating English medium content knowledge, there is scarcity of discussion on ESEP practitioners' challenges at Malaysian focus universities. Hence, this study calls for an investigation on ESEP practitioners' pedagogical practices at the local technical and engineering higher education instititutions. Specifically, the objectives are to explore the experts' views on challenges and competencies required by the practitioners in facilitating ESEP, and to find out the practitioners' view on the required competencies in overcoming the challenges.

\section{LITERATURE REVIEWS}

\subsection{The critical EAP theory}

The Critical EAP theory by Benesch [14] that supports this study is influenced by Henri Giroux's critical pedagogy on practitioners' disaffection with their current status quo [15]. The theory "appeal to teachers who are unhappy with current conditions, seeking ways to bring about pedagogical, institutional, and social change on behalf of and with their [learners]" [14]. The theory advocates pedagogy as part of knowledge production, hence implicates how learners' identities were produced [16]. This is to emphasise that "different forms of pedagogy produce different types of knowledge and learners" identity". Hence, it is vital for ESEP practitioners to critically realise the impact of their competencies because it affects their learners' identity.

Moreover, the facilitation of academic language using technical and engineering academic tasks, texts and content has accorded ESEP a highly pragmatic approach. ESEP pragmatism that accentuates on constant investigations of needs [17] has left minimal choice for ESEP practitioners to conform to what [18] contend ESEP as "an approach to language teaching in which all decisions as to content and method are based on the learner's reason for learning". This conformity to content field has reduced ESEP practitioners' status as "the butlers" [14]. The pragmatism assumes ESEP practitioners to subordinate their instruction to the demands, behaviours and arrangements, "perpetuating a subordinate role to content discipline practitioners" [14]. The "primacy and narrowness of faculty perceptions surrounding ESL learners' performance along with the unequal power relations" [19] expects ESEP practitioners not to question the practicality of pedagogical activities. Therefore, the theory urges ESEP practitioners to be critical when teaching disciplinary content, rather than passively accommodating [20], as conventionally assumed in most ESEP settings.

\subsection{The specifity of ESEP}

With regards to the specificity of ESEP, which should be in accordance to the content fields, [18] brings forth three challenges. The three are the lack of convention to provide a readymade guide, the new fields of knowledge ESEP practitioners have to cope, and the change in ELT status. Firstly, the lack of convention for readymade ESEP pedagogical materials have led to issues of 'authenticity'. The issue of not having specific guideline in using authentic or inauthentic materials has caused uncertainties among ESEP practitioners. The practitioners need to decide on the role of materials before it can be adapted to be used. The decision is based on general guidelines and the solution is rather not conclusive.

Secondly, learners' knowledge of subject content is another hurdle for practitioners who have only general English (GE) training. GE requires functional literacy or communicative competence in social settings using ready-made materials whereas ESEP involves engineering specialist knowledge and language of the specific field [21]. The challenges are in terms of the material specificity, the difficulty of ESEP practitioners to comprehend the subject matter, and the kind of knowledge ESEP practitioners need. ESEP practitioners need both content and formal schema knowledge in the engineering field so that the practitioners can be advisors and facilitators of learners' communicative practices [22], as well as collaborators, researchers, and evaluators of the materials they have provided for learners' learning [23]. These roles require considerable amount of effort and time, which could necessitate the practitioners' change 
of attitude in ensuring effectual learning. The uneasiness to comprehend the subject matter is actually derived from the practitioners' reluctance to get out of the comfort zone, which is usually confined in the teaching of Literature and social English [18]. Additionally, the fact that their status "changes from being a subject to a service industry for other specialism" is the cause for some inferiority feeling in them [18]. This feeling however, is common. Hence, there is an inevitable need for a close cooperation with the subject specialists.

As individuals, Savaş characterises ESEP practitioners as professionals whose values are more than the pedagogical traits [24]. The practitioners should be willing to learn, possess some knowledge of content subjects, work well in a team, listen to and motivate learners, and are critical in thinking. ESEP practitioners also carry responsibilities to keep context and comprehensibility in their instruction, select and adapt authentic materials for lessons, provide scaffolding for learners' linguistic content learning, and create learner-centred classrooms. Attan, et al. anticipate the practitioners to integrate or imbed professional values that are required at engineering related workplaces especially in terms of learners' communication [7]. Bracaj also supports the inclusion of attitude or values in the practitioners' roles apart from the existing knowledge and skills justified in related ESAP literature [9]. This means apart from teaching, providing materials, designing a syllabus, collaborating with subject specialists, conducting research and evaluating the course and learners as listed by the earlier studies, ESEP practitioners' roles have matured with some values or attitudes attached.

Mishra further specifies the values in the roles along with the shift of ESEP from pedagogy to andragogy because the nature of ESEP learners who are already in a specific field of studies, possess schemata in the language, and are driven by their need to know [25]. These sorts of learners actually require andragogical approach than those prescribed by pedagogical model [26] which differs in terms of their qualification and passion for teaching; knowledge on recent developments in specific fields; skill and patience in developing learners' skills; engagement in research and publication works to create learner centric classroom; recognition as language specialists within a specific field; and application of to-date classroom techniques and activities. For that reasons, the diversified nature of ESEP has granted the term 'practitioners' instead of instructors [27], which indeed, carried more complex roles and responsibilities than as 'educators' [9]. Above all, ESEP practitioners requires more than pedagogical knowledge and skills; it has expanded in its practices and values, in light of its learners' needs and what it requires. This therefore, calls for investigations on the challenges faced by ESEP practitioners, before specific ESEP practitioners' competency can be identified.

\subsection{ESEP practitioners' competencies}

Competencies have been interchangeably used with different names and causally linked to performance or as sets of desirable behaviours. Woollacott outlines competency in three elements [28]: a latent, acquired or developed attribute possessed by a person; related to the intentional execution of tasks; implied a value judgment on the quality of the ability, capacity or characteristic against formally or informally defined criteria

'Competency' in this study therefore includes personality traits rather than solely on the overall achievement-oriented behaviour [29]. Therefore, based on the challenges discussed earlier, the experts and ESEP practitioners' viewpoints are collected in identifying the required competency for ESEP practitioners. This is because the experts and practitioners are the individuals who have faced the challenges. It is well assumed that the practitioners know best what is required for their ESL engineering learners. Situating this study in Malaysian engineering HE contexts, three Malaysian Teacher Standards [30] principles (values, knowledge and skills) are adapted in identifying the competencies for ESEP practitioners.

\section{RESEARCH METHOD}

This study used both quantitative and qualitative inquiries in achieving the aim of the study. Two groups were selected to be included in the study i.e. ESAP/ESEP experts and practitioners from four public technical and engineering tertiary institutions.

Data collection processes began with series of interview sessions with 14 identified experts. A list of semi structured interview questions was used to generate the experts' professional viewpoints. Later, an online survey on the practitioners was carried out for them to self-assess their competencies. A five-Likert scale of importance questionnaire which comprised items from the three MTS principles were adapted and made available online. There were 42 ESEP practitioners responded voluntarily. The instruments went through several tests to ensure their trustworthiness and authenticity, as well as its validity and reliability.

Braun and Clarke's six-stage method of thematic analysis (TA) was used to analyse the qualitative data [31] and Atlas.ti to aid the presentation of data. The quantitative data were analysed using mean scores for the three principles. 


\section{RESULLS AND DISCUSSION}

Findings from the qualitative inquiry revealed several challenges that were classified under the three major themes which were the three principles from [30] see in Table 1. The first theme was on ESEP practitioners' challenges on the lack of guideline for specific professional values required in ESEP learning and facilitating in technical and engineering field. Most of the experts made connections between professional values and soft skills that were needed by ESEP practitioners. They also put forth the importance of professional values especially when catering to learners' needs in learning ESEP courses (Learner Focus). It was known for a fact that their learners were already in their chosen field of studies (engineering), possess schemata in the language, and were driven by their need to know. Concurrent with the literature, the experts recommended the shift of from pedagogy to andragogy approach. Note that the andragogical approach has different teaching methods and practices as discussed earlier. Also, the experts agreed with Javid's [27] on the diversified nature of ESEP which has granted the term 'practitioners' because ESEP responsibilities have expanded in definitions and practices in light of its learners' needs and what it requires in facilitating ESEP courses.

Table 1. The challenges in facilitating ESEP

\begin{tabular}{|c|c|c|c|}
\hline $\begin{array}{l}\text { Themes/ } \\
\text { Challenges }\end{array}$ & ESEP Professional Values & Knowledge \& Understanding of ESEP & $\begin{array}{l}\text { Learning \& Facilitating } \\
\text { ESEP Skills }\end{array}$ \\
\hline Codes & $\begin{array}{ll}- & \text { Soft Skills } \\
- & \text { Learner Focus (andragogy) } \\
\text { - } & \text { Practitioners }\end{array}$ & $\begin{array}{ll}- & \text { Knowledge of Technical } \\
- & \text { General English (GE) vs Specific } \\
& \text { (ESP) }\end{array}$ & $\begin{array}{ll}\text { - } & \text { Engineering Academic Context } \\
\text { - } & \text { Workplace Requirement }\end{array}$ \\
\hline
\end{tabular}

Second theme was on the knowledge and understanding required in the learning and facilitating a specific field like for technical and engineering education. Majority of the experts were equally insistent of the significance of technical knowledge and understanding. However, the challenges are in terms of the material specificity and authenticity, the difficulty to comprehend the subject content and the kind of knowledge ESEP practitioners need. For that, ESEP practitioners were advised to look at the whole purpose of learning. A teaching material that causes difficulties to the practitioners can deter meaningful learning and creating less interest among learners. The solution then, depends on the practitioners' competency in selecting materials 'that accommodate their own capacities'. In this sense, this is the advantage of ESEP practitioners who play the role as syllabus designers and material writers in contrast to the GE educators who have no power on syllabuses and materials selection. Acquiring some technical knowledge of engineering would be an advantage to the practitioners. Nevertheless, the experts voiced concern on the extent of the required ESEP technical knowledge and understanding.

As for the third, most of the experts believed the skills of ESEP learning and teaching complimented the other two domains. The experts agreed that ESEP practitioners needed the skills in relating their learning and facilitating practices with the engineering academic contexts and in accommodating ESL engineering learners' workplace requirements. Interestingly, the importance of the skill echoed the experts' view on the fact that the learners were adults who already possessed the schemata in the language and were driven by their needs [25] to learn technical and engineering related contents. Consistently, this reiterated the perceptible need for a shift in ESEP learning and facilitating to andragogical approach.

In overall, the experts admitted the seriousness of the challenges faced by the ESEP practitioners and cautioned on its negative effects to the practitioners' classroom practices, as posed by Benesch [14]. Conversely, the challenges, if it is tackled strategically, could uplift the practitioners' significance in becoming the language specialist in the field especially with regards to MTS, which aims at generating successful professional practices in academic field based on the national standards.

The findings from the quantitative analyses concurred with the qualitative on the importance of ESEP knowledge and understanding as the prevalent competency for the practitioners in overcoming the identified challenges see in Table 2.

Table 2. Mean scores for each principle of the competency

\begin{tabular}{lccc}
\hline \multirow{2}{*}{ Competency } & Principle I & Principle II & Principle III \\
& ESEP Professional Values & Knowledge \& Understanding & ESEP Learning \& Facilitating Skills \\
\hline Mean Scores & 0.754 & 0.795 & 0.794 \\
\hline
\end{tabular}

Int. J. Eval. \& Res. Educ. Vol. 8, No. 4, December 2019: 699 - 704 
The practitioners viewed ESEP knowledge and understanding as the most significant competency, as compared to Skills and Values. The lack of technical knowledge and understanding as revealed in the qualitative findings had caused the practitioners the difficulties in preparing materials for ESEP learning and teaching practices. The lack of technical knowledge and understanding concurred with the allegations on reasons why ESL practitioners were found incapable of teaching language and communication skills in engineering fields. As remarked by Hutchinson and Waters, the practitioners felt uncertain due to lack of convention for readymade ESEP teaching and learning materials [18, 21]. The specificity in ESEP was a crucial matter on the basis that each professional and academic discourse comprised a variety of specific literacies. The variations in engineering professional discourses, which were espoused by text analysis researches, existed in terms of contents, topics and vocabularies [4].

To add, ESEP knowledge and understanding was also required in differentiating GE and ESEP. This was essential because GE has different objectives and offers more general language skills that had no specific connection with the content field. Evidently, the quantitative findings supported the second principle (Knowledge and Understanding of ESEP) as the most important principle for ESEP practitioners' competency in overcoming most of the mentioned difficulties. The practitioners believed that acquiring knowledge and understanding of engineering academic and professional needs could help them to break away from the 'uneasiness' in comprehending the 'unpredictable and unfamiliar' technical and engineering contents.

\section{CONCLUSION}

The ESL ESEP practitioners' challenges were comparable with the literature but, not much attention has been given in specifiying the required competencies for specific academic field. Clearly, the ESEP practitioners' need specific competencies for effectual ESEP learning and facilitating. The study adapted the three MTS principles of competencies to classify the practitioners' challenges. According to the experts, the challenges occurred due to the inadequacy of guidelines for ESEP practitioners' specific professional values, the extent of technical knowledge and understanding, and ESEP specific learning and facilitating skills. Particularly on the need for ESEP knowledge and understanding, the practitioners accorded the principle as the most significant competency in in overcoming most of the mentioned challenges.

The findings reasserted the overlooking of ESEP practitioners' competency in dealing with the challenges, and its significant effects on learners, and in supporting the content subject. The findings also highlighted the required ESEP competencies, which could lead to information on professional development training for the practitioners in elevating the practitioners' status and recognition as the language specialists in the field of technical and engineering at those institutions. It further implicated the need for the local quality agencies to specify ESEP practitioners' qualifications, in contrast to other GE practitioners. The guidelines also could facilitate the practitioners in preparing suitable communicative activities that centre on learners' purpose of learning the language and skills.

The findings from this study do not allow for generalization; however, they provide insights to the critical issues in ELT to engineering learners. To meet the demands of engineering workforce in the era of global mobility it is important to ensure exchange and sharing of ideas and practices among all stakeholders particularly, the ESEP practitioners. The practitioners' perspectives and active involvement in the engineering academic and workplace preparation are equally important in improving learners' English and communicative skills especially in augmenting the significance of interdisciplinary learning between language and engineering. The epistemological studies specifically in catering to ESL engineering learners' academic needs and job preparation have become crucial with the increased priority of professional skills and work integrated curricula in the field.

\section{ACKNOWLEDGEMENTS}

This research and publication are supported by the Malaysian Fundamental Research Grant Scheme (FRGS) grant (FRGS/1/2016/SS09/UMP/03/1).

\section{REFERENCES}

[1] Basturkmen, H., "Languages for specific purposes curriculum creation and implementation in Australasia and Europe," The Modern Language Journal, vol. 96(1), pp. 59-70, 2012.

[2] Nordin, R., "Technical communication skills among recent electrical and electronics engineering graduates in job industries," Global Journal of Engineering Education, vol. 15(3), pp. 160-164, 2013.

[3] Basturkmen, H., "Ideas and options in English for specific purposes," Routledge, 2014. 
[4] Hyland, K., "General and specific EAP," in The Routledge Handbook of English for Academic Purposes, pp. 41-53, Routledge, 2016.

[5] Felder, R.M., Brent, R., \& Prince, M.J., "Engineering instructional development: programs, best practices, and recommendations," Journal of Engineering Education, vol. 100(1), pp. 89-122, 2011.

[6] Puteh, M., \& Mohd Ismail, K., "Quality assurance through innovation policy: The pedagogical implications," in Human Resources Management: Concepts, Methodologies, Tools, and Applications: Concepts, Methodologies, Tools, and Applications, pp. 40-49, 2012.

[7] Attan, A., Abdul Raof, A.H., Hamzah, M., Abdullah, K.I. \& Mohd Omar, N.A., "Developing a profile of workplace written communication," Procedia-Social and Behavioral Sciences, vol. 70, pp. 969-978, 2013.

[8] Alexander, O., "Exploring teacher beliefs in teaching EAP at low proficiency levels," Journal of English for Academic Purposes, vol. 11(2), pp.99-111, 2012.

[9] Bracaj, M., "Teaching English for specific purposes and teacher training," European Scientific Journal, vol. 10(2), pp. 40-49, 2014.

[10] Arnó-Macià, E., \& Mancho-Barés, G., "The role of content and language in content and language integrated learning (CLIL) at university: Challenges and implications for ESP," English for Specific Purposes, vol. 37, pp. 63-73, 2015.

[11] Shatrova, Z., "Teaching English to engineering students in the contemporary world: A case study on a Ukrainian and Turkish universities," Journal of Education and Practice, vol. 5(11), pp.149-156, 2014.

[12] Wu, H.D., \& Badger, R.G., "In a strange and uncharted land: ESP teachers' strategies for dealing with unpredicted problems in subject knowledge during class," English for Specific Purposes, vol. 28(1), pp. 19-32, 2009.

[13] Melles, G., Millar, G., Morton, J., \& Fegan, S., "Credit-based discipline specific English for academic purposes programmes in higher education: revitalizing the profession," Arts and Humanities in Higher Education, vol. 4(3), pp. 283-303, 2005.

[14] Benesch, S., "Critical English for Academic Purposes: Theory, Politics and Practice," New Jersey, Lawrence Erlbaum Associates, 2001.

[15] Giroux, H., "Pedagogy and the Politics of Hope: Theory, Culture and Schooling," Boulder, CO, Westview Press, 1997.

[16] Scott, D., "Critical Essays on Major Curriculum Theorists," New York, Routledge, 2008.

[17] Charles, M., "Proper vocabulary and juicy collocations': EAP students evaluate do-it-yourself corpus-building," English for Specific Purposes, vol. 31(2), pp. 93-102, 2012.

[18] Hutchinson, T., \& Waters, A., "English for Specific Purposes: A Learning-Centered Approach," Cambridge, Cambridge University Press, 1987.

[19] Carkin, S., "English for academic purposes," in Hinkel, E. (Ed.) Handbook of Research in Second Language. Teaching and Learning, pp. 85-98, Mahwah, New Jersey, Lawrence Erlbaum Associates, 2005.

[20] Morgan, B., "Fostering transformative practitioners for critical EAP: possibilities and challenges," Journal of English for Academic Purposes, vol. 8(2), pp. 86-99, 2009.

[21] Kaewpet, C., "Learning needs of Thai civil engineering students," The Asian ESP Journal, vol. 7(3), pp.79-105, 2011.

[22] Dudley-Evans, T., \& St John, M., "Developments in English for specific purposes: A multi-disciplinary approach," UK, Cambridge University Press, 1998.

[23] Fei, W.F., Ming, T.S., Mohd Noor, N., Latif, H., \& Abd Aziz, M.S., "A blended approach in teaching an EAP course: Malaysian instructors' perceptions of the new course materials," 3L; Language, Linguistics and Literature, vol.18(3), pp. 103-117, 2012.

[24] Savaş, B., "Role of functional academic literacy in ESP teaching: ESP teacher training in Turkey for sustainable development," Journal of International Social Research, vol. 2(9), pp. 395-406, 2009.

[25] Mishra, S., "Role and need of ESP in engineering education: A case study of status in Odisha, India," Asian Journal of Social Sciences \& Humanities, vol. 3(3), pp. 194-201, 2014.

[26] Minter, L., "The learning theory jungle," Journal of College Teaching \& Learning, vol. 8(6), pp. 7-16, 2011.

[27] Javid, C.Z., "English for specific purposes: Role of learners, teachers and teaching methodologies," European Scientific Journal, vol. 11(20), pp. 1857-7881, 2015.

[28] Woollacott, L.C., "Taxonomies of engineering competencies and quality assurance in engineering education". In Patil, A. \& Gray. P. (Eds.), Engineering Education Quality Assurance: A Global Perspective, pp. 257-294, New York, Springer, 2009.

[29] Matulcikova, M., \& Brevenikova, D., "Knowledge and skills of professional communication as the employability support factor," European Scientific Journal, vol. 11(1), pp. 253-266, 2015.

[30] Malaysian Teacher Standards (MTS), Teacher Education Division, Putrajaya, 2009.

[31] Braun, V., \& Clarke, V., "Using thematic analysis in psychology," Qualitative Research in Psychology, vol. 3(2), pp. 77-101, 2006. 